\title{
MECHANICAL PROPERTIES OF RECYCLED AGGREGATE CONCRETE USING BENTONITE AND ROBO SAND-AN EXPERIMENTAL STUDY
}

\author{
Shaista Begum ${ }^{1}$, Mohd. Waleed Hassan Ansari ${ }^{2}$ \\ ${ }^{I}$ AssociateProfessor, Civil Engineering, Deccan College of Engineering and Technology, Darussalam, Hyderabad, \\ 500001, TS, India. \\ ${ }^{2}$ M.E Scholar, Civil Engineering, Deccan College of Engineering and Technology, Darussalam, Hyderabad, 500001, \\ TS, India.
}

\begin{abstract}
The utilization of concrete has been increasing day by day due to rapid industrialization, urbanization and infrastructural developments all over the world. A huge quantity of natural coarse aggregate, natural river sand and also cement is needed in order to fulfill the increasing demand. This is causing a rapid depletion of the natural resources, be it rocks for coarse aggregate or the natural river sand and need to be conserved urgently. It is also found that during the production of cement, an equal amount of carbon dioxide is also produced and to overcome the ill effects caused on the environment, attempts have been made to replace the natural resources by some other materials such as recycled aggregates and ROBO sand and cement by some other binding material like bentonite. This work reports the results of an experimental study on the mechanical properties of concrete produced with recycled coarse aggregate (100\%), ROBO sand (100\%) and partial replacement of cement with Bentonite (0\%, $5 \%, 10 \%, 15 \%, 20 \%, 25 \%$ and 30\% replacement). The compressive strength, split tensile strength and flexural strength of this concrete was tested by casting cubes of size $150 \times 150 \mathrm{~mm}$, cylinders of diameter $150 \mathrm{~mm}$ and length $300 \mathrm{~mm}$ and beams of length $500 \mathrm{~mm}$ and cross sectional dimensions $100 \times 100 \mathrm{~mm}$ size respectively and testing was done at 7 and 28 days. The fresh and harden concrete properties were analysed after 28 days of curing and found that at 20\% replacement of OPC with bentonite along with super plasticizer was optimum and gave compressive strength of $44.0 \mathrm{~N} / \mathrm{mm} 2$ which is an increase of about $17.5 \%$. Similarly the split tensile strength is found to $12 \%$ more than at $0 \%$ bentonite.. The workability was a problem initially but was able to achieve after addition of super plasticizer.
\end{abstract}

Keywords: - recycled aggregate, Bentonite, Robo sand, Natural aggregate, Super Plasticizer. ****

\section{INTRODUCTION}

About 7.5 billion cubic meters of concrete is produced each year, more than one cubic meter for every person on the Earth. Production of concrete requires a host of material resources in terms of cement, sand and aggregates. Most of these materials used in concrete are naturally occurring and due to their extensive use are becoming scarce. River sand sources are fast depleting and the quantity of sand required is falling short of demand. To overcome this deficit, alternative material to river sand, namely manufactured stone crushed sand or ROBO sand is being used in the industry in making concrete. It is well known fact that even aggregates are depleting and an alternative resource needs to be recognized and tried. The Countries who have faced with issues pertaining to shortage of supply of raw materials have already switched on to recycling for meeting their requirement. As a large proportion of this requirement can be supplemented by using the demolished material, nevertheless this secondary material needs to be assessed before being used in making of second generation concrete. This work tests such demolished material as an alternative material to be used in concrete by recycling thus saving onto the natural resources and also satisfying the social and environmental objective. Bentonite is a kind of clay that swells and gels when mixed in water which is used in construction majorly in excavation and foundation works. It consists of more than $85 \%$ clay mineral called 'montmorillonite' and is considered to be high plastic clay. The use of bentonite as an important construction element is still in its initial stages, since a major percentage of foundations and other civil engineering activities are still constructed without the use of bentonite and are causing higher expenditure through the use of cast iron and steel liners. In this present study the attempt is made to use the recycled aggregate in new concrete without compromising the properties of fresh and harden concrete i.e., compressive strength, tensile strength and workability and to investigate the possibility of using bentonite and robo sand to improve the quality of RAC. The suitability of bentonite for the production of structural concrete, having been classified as highly reactive pozzolona, is not only considered as "green" and environmental friendly construction material, but also useful in the quest to reduce the cement constituents 
of concrete production. Thus the use of bentonite will greatly reduce the environmental pollution, cost of construction, emission of carbon dioxide by reducing the cement content. Chemical admixture i.e., Super plasticizer of about $0.8 \%$ of weight of binding material is used you improve its workability. Grading, Specific gravity test and water absorption tests are conducted on fine aggregate and recycled Aggregates.LosAngeles test is also performed to find recycled aggregate's resistance to abrasion. Compression tests, Split tensile strength tests, flexural tests and workability tests are conducted $[12,13]$.

\section{EXPERIMENTAL INVESTIGATIONS}

\subsection{Materials}

The following materials are used for the casting of Specimens:

2.1.1 Cement: In the present investigation, ordinary Portland cement of type cement of 53 Grade (Ultra tech) is used. Care is taken that is freshly produced and from a single producer. The cement thus produced was tested for physical properties in accordance with IS 4031.

2.1.2 Fine Aggregate: Fine aggregate is Robo sand obtained locally. The physical properties like specific gravity was determined in accordance with IS 383-1970[13]. Fineness modulus was found based on sieve analysis. Weight of sample taken was 1000 grams.

2.1.3 Recycled Coarse Aggregate: Recycled course aggregate of $20 \mathrm{~mm}$ maximum size of angular shape obtained from recycled aggregate crushing plant, Osmania University, Civil Engineering Department, in Hyderabad is used in present study. Specific gravity was determined in accordance with IS 2386.

2.1.4 Water: Locally available portable water was used for mixing and curing which is portable and free from injurious substances that may be deleterious to concrete or steel.

2.1.4 Bentonite: Bentonite used in the present investigation is calcium bentonite obtained from a construction material supplier located at Secunderabad and the surface area of bentonite is 0.09 to $1.8 \mathrm{~m}^{2} / \mathrm{cc}$ and specific gravity is 2.6.Table 1 shows the details of the properties of bentonite.

2.1.6 Super Plasticizer: The super plasticizer used in this investigation Roofplast SP-45 from Armstrong chemicals Ltd.

\section{METHODOLOGY}

The properties of cement such as normal consistency, specific gravity, fineness etc., and the properties of fine aggregates, natural coarse and recycled coarse aggregates like specific gravity, grain size, and water absorption are determined using the suitable test procedures. The details of the M60grade Concrete mix used are tabulated in Table 2 is arrived at as per IS: 10262[14]. Workability test on concrete with different water-cement ratio was carried out. Concrete cubes of size $150 \times 150 \times 150 \mathrm{~mm}$ were casted in moulds as per the mix proportions obtained for determining the compressive strength and cylinders of diameter $150 \mathrm{~mm}$ and height $300 \mathrm{~mm}$ for cylindrical specimen were casted for determining the split tensile strength, cured for 7days and 28 days and tested following standard procedures and Beams of size $100 \mathrm{mmx} 100 \mathrm{~mm} \times 500 \mathrm{~mm}$ were casted and tested for flexural strength.

\section{DISCUSSION OF RESULTS}

\subsection{Workability}

Workability of the samples was decreasing with the increase in the percentage of bentonite. This was because the bentonite particles were absorbing certain amount of mixing water on its surface resulting in decrease in the free water and lowering the workability. Table 3 shows the workability variance with the variation in percentage of bentonite. (Fig.1)

\subsection{Compressive Strength}

The Compressive strength of the cubes is given in the Table 4. In the present research it can be seen that at the end of 7 days, there was increase in the compressive strength of about $8 \%$ when about $10 \%$ bentonite is used and $10 \%$ when $15 \%$ bentonite was used. This compressive strength increases more, about $11 \%$ when $20 \%$ bentonite is used but the compressive strength decreases about $16.5 \%$ when $30 \%$ bentonite used. The results at the end of 28 days show increase in compressive strength of about $6 \%$ when $10 \%$ bentonite used, increase of about $13 \%$ when $15 \%$ bentonite is used and an increase of $17.5 \%$ when $20 \%$ bentonite was used. But there is a decrease of about $16 \%$ when $30 \%$ bentonite is used.

The comparative results of compressive strength at 28 days are shown in fig 2.

\subsection{Split Tensile Strength}

The split tensile strength of the cylinders of seven different batches is shown in the table 5. It is to be noted that from the literature review done we have seen that the compressive strength, split tensile strength and flexural strength of the concrete which is cast by replacing the coarse aggregate completely by recycled aggregate (100\% replacement) is significantly lower than that compared with the concrete cast out of natural coarse aggregate for all concrete grades. The results obtained in this research are to be compared with the results achieved for the samples which consist of $100 \%$ replacement of natural coarse aggregate with the recycled aggregate and $0 \%$ Bentonite. The 28 day results show that the split tensile strength was lower by $17 \%, 14 \%, 10 \%, 7 \%$ and $2.5 \%$ for $5 \%, 10 \%, 15 \%, 20 \%$ and $25 \%$ bentonite replacement. The split tensile strength for $30 \%$ was found to be the same. Figure 4 showing the comparative split tensile strength at the end of 28 days.

The flexure strength of the cylinders of seven different batches is shown in the table 5.At the end of 28 days, the flexure strength of $5 \%$ and $10 \%$ bentonite replacement was 
lower than $100 \%$ recycled aggregate ( $0 \%$ bentonite) by $14 \%$ and $7 \%$ respectively. Whereas, the flexural strength was found to be more, about $5 \%, 12.5 \%, 15 \%$ and $17 \%$ for $15 \%$,
$20 \%, 25 \%$ and $30 \%$ bentonite replacements respectively. Figure 5 showing the comparative results of flexural strength at the end of 28 days.

Table 1: Showing physical properties of Bentonite

\begin{tabular}{|c|c|c|}
\hline S. No & Physical Property & Value \\
\hline 1 & $\begin{array}{c}\text { Uncompacted } \\
\text { Density }\left(\mathrm{lbs} . / \mathrm{ft}^{3}\right)\end{array}$ & 47.5 \\
\hline 2 & $\begin{array}{c}\text { Compacted Density } \\
\left(\mathrm{lbs} . / \mathrm{ft}^{3}\right)\end{array}$ & 2.6 \\
\hline 3 & Specific gravity & Odorless granules or \\
\hline 4 & Appearance & 0.09 to 1.8 \\
\hline 5 & Surface area $\left(\mathrm{m}^{2} / \mathrm{cc}\right)$ & None \\
\hline 6 & Solubility in water & 8.5 to 10.5 \\
\hline 7 & $\mathrm{pH}$ & Light cream \\
\hline 8 & colour & \\
\hline
\end{tabular}

Table 2: showing the quantity of materials for M60 grade concrete

\begin{tabular}{|c|c|c|}
\hline S.No & Material $\left(\mathrm{kg} / \mathrm{m}^{3}\right)$ & Quantity of materials $\left(\mathrm{kg} / \mathrm{m}^{3}\right)$ \\
\hline 1 & Cement & 517 \\
\hline 2 & Water & 155 \\
\hline 3 & Fine Aggregate & 607.75 \\
\hline 4 & Coarse Aggregate & 1037.84 \\
\hline 5 & Super Plasticizer & $2 \%$ by weight of binding material \\
\hline 6 & Water Cement Ratio & 0.3 \\
\hline 7 & Workability & $100 \mathrm{~mm}$ \\
\hline
\end{tabular}

Cement: Fine aggregate: Coarse aggregate is 1:1.17:2 with water-cement ratio 0.3

Table 3: showing workability in terms of slump

\begin{tabular}{|c|c|c|}
\hline S.No & Mix ID & Slump in $\mathrm{mm}$ \\
\hline 1 & B1 (0\% Bentonite) & 86 \\
\hline 2 & B2 (5\% Bentonite) & 81 \\
\hline 3 & B3 (10\% Bentonite) & 75 \\
\hline 4 & B4 (15\% Bentonite) & 69 \\
\hline 5 & B5 (20\% Bentonite) & 62 \\
\hline 6 & B6 (25\% Bentonite) & 58 \\
\hline 7 & B7 (30\% Bentonite) & 55 \\
\hline
\end{tabular}

Workability in mm

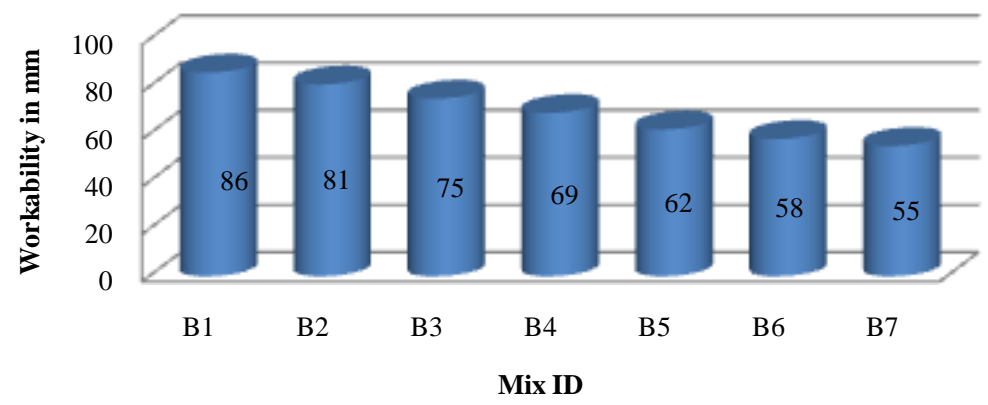

Fig 3: showing the variation of workability in terms of slump 
Table 4: Results of the compressive strengths of cubes at 7 and 28 days

\begin{tabular}{|c|c|c|c|}
\hline S.No & Mix ID & $\begin{array}{c}\text { Compressive } \\
\text { strength at 7 } \\
\text { days (MPa) }\end{array}$ & Compressive strength at 28 days (MPa) \\
\hline 1 & $\begin{array}{c}\text { B1 (0\% } \\
\text { Bentonite) }\end{array}$ & 24 & 37.18 \\
\hline 2 & $\begin{array}{c}\text { B2 (5\% } \\
\text { Bentonite) }\end{array}$ & 25 & 37 \\
\hline 3 & $\begin{array}{c}\text { B3 (10\% } \\
\text { Bentonite) }\end{array}$ & 25.9 & 39.51 \\
\hline 4 & $\begin{array}{c}\text { B4 (15\% } \\
\text { Bentonite) }\end{array}$ & 26.3 & 44 \\
\hline 5 & $\begin{array}{c}\text { B5 (20\% } \\
\text { Bentonite) }\end{array}$ & 26.7 & 38 \\
\hline 6 & $\begin{array}{c}\text { B6 (25\% } \\
\text { Bentonite) }\end{array}$ & 24.5 & 31 \\
\hline 7 & $\begin{array}{c}\text { B7 (30\% } \\
\text { Bentonite) }\end{array}$ & 20 & 42 \\
\hline
\end{tabular}

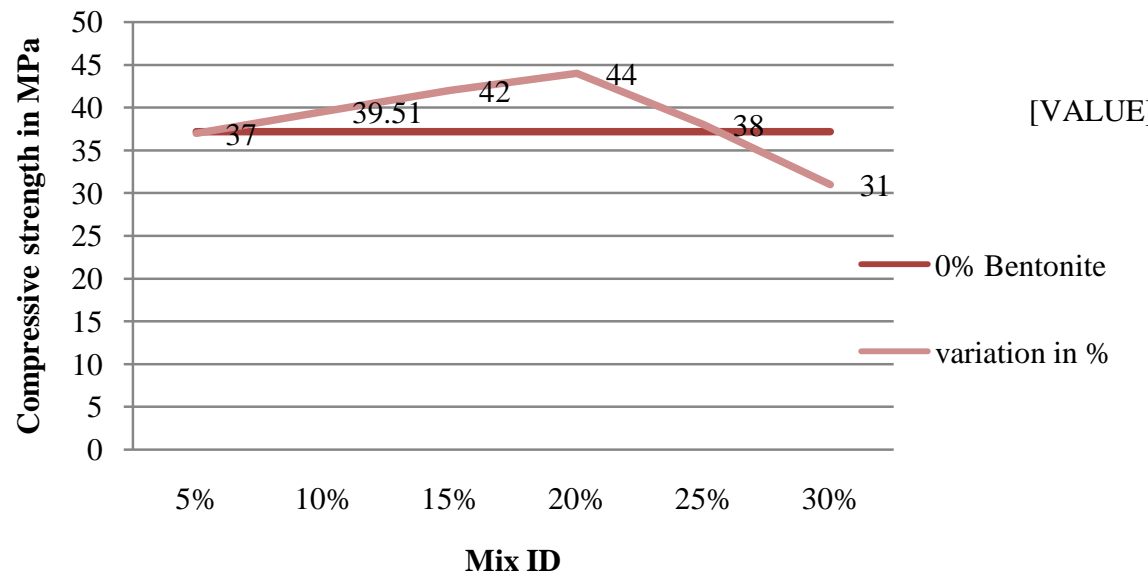

Fig 1: showing the comparative results of compressive strengths at 28 days

Table 5 Results of the split tensile strength at the end of 7 and 28 days

\begin{tabular}{|c|c|c|c|}
\hline S.No & Mix ID & $\begin{array}{c}\text { Split tensile strength at } \\
7 \text { days }(\mathrm{MPa})\end{array}$ & $\begin{array}{c}\text { Split tensile } \\
\text { strength at 28 days } \\
(\mathrm{MPa})\end{array}$ \\
\hline 1 & B1 (0\% Bentonite) & 2.46 & 2.91 \\
\hline 2 & B2 (5\% Bentonite) & 1.86 & 2.4 \\
\hline 3 & B3 (10\% Bentonite) & 1.95 & 2.5 \\
\hline 4 & B4 (15\% Bentonite) & 2.07 & 2.62 \\
\hline 5 & B5 (20\% Bentonite) & 2.2 & 2.7 \\
\hline 6 & B6 (25\% Bentonite) & 2.46 & 2.83 \\
\hline 7 & B7 (30\% Bentonite) & 2.67 & 2.91 \\
\hline
\end{tabular}




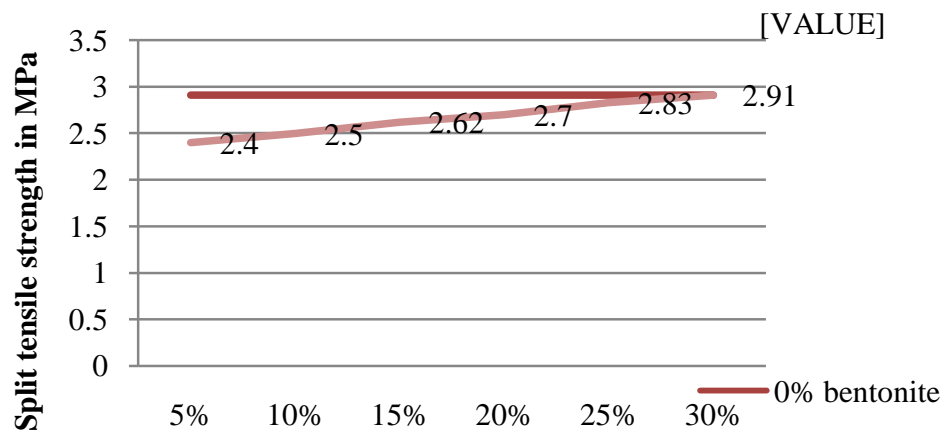

Mix ID

variation in $\%$

Fig 2: showing the comparative split tensile strength at the end of 28 days

Table 6: Results of the flexural strength at the end of 7 and 28 days

\begin{tabular}{|c|c|c|c|}
\hline S.No & Mix ID & $\begin{array}{c}\text { Flexure } \\
\text { strength at 7 } \\
\text { days (MPa) }\end{array}$ & $\begin{array}{c}\text { Flexure strength at 28 days } \\
\text { (MPa) }\end{array}$ \\
\hline 1 & $\begin{array}{c}\text { B1 (0\% } \\
\text { Bentonite) }\end{array}$ & 3.25 & 3.73 \\
\hline 2 & $\begin{array}{c}\text { B2 (5\% } \\
\text { Bentonite) }\end{array}$ & 3 & 3.2 \\
\hline 3 & $\begin{array}{c}\text { B3 (10\% } \\
\text { Bentonite) }\end{array}$ & 3.18 & 3.47 \\
\hline 4 & $\begin{array}{c}\text { B4 (15\% } \\
\text { Bentonite) }\end{array}$ & 3.5 & 3.93 \\
\hline 5 & $\begin{array}{c}\text { B5 (20\% } \\
\text { Bentonite) }\end{array}$ & 3.85 & 4.2 \\
\hline 6 & $\begin{array}{c}\text { B6 (25\% } \\
\text { Bentonite) }\end{array}$ & 3.96 & 4.29 \\
\hline 7 & $\begin{array}{c}\text { B7 (30\% } \\
\text { Bentonite) }\end{array}$ & 4.1 & 4.37 \\
\hline
\end{tabular}

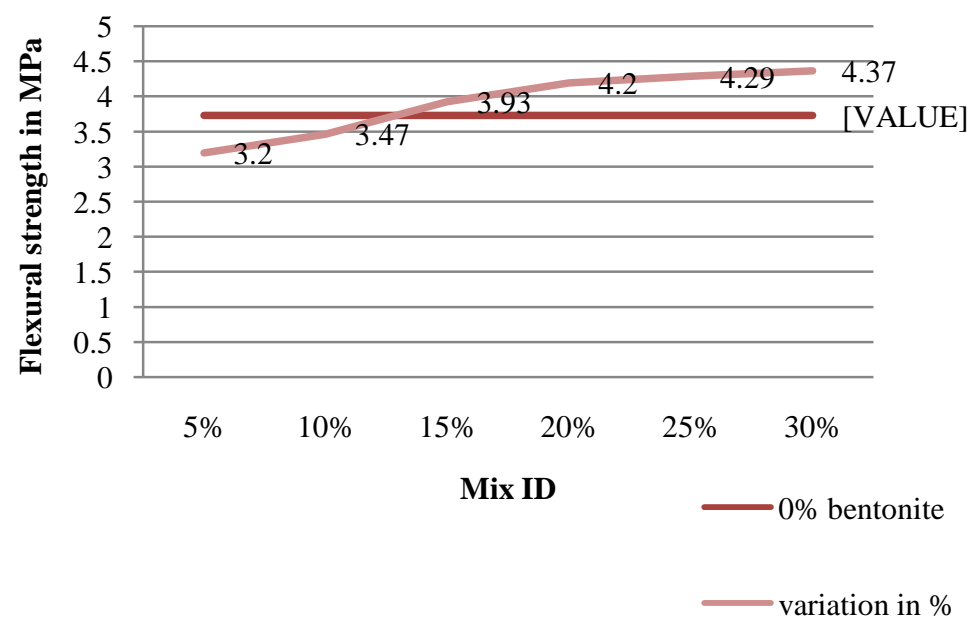

Fig 4: Showing the comparative results of flexural strength at the end of 28 days 


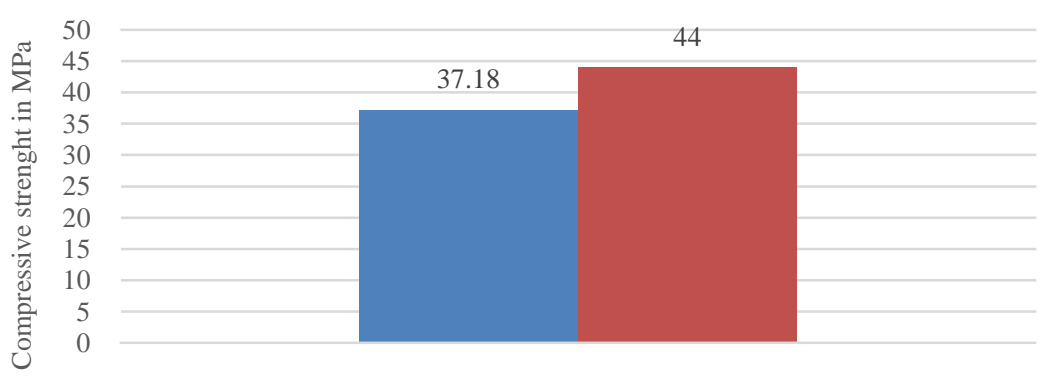

Compressive strength at $0 \%$ vs $20 \%$ Bentonite.

- $0 \%$ Bentonite $\quad 20 \%$ Bentonite

Fig 5: compressive strength at $0 \%$ vs $20 \%$

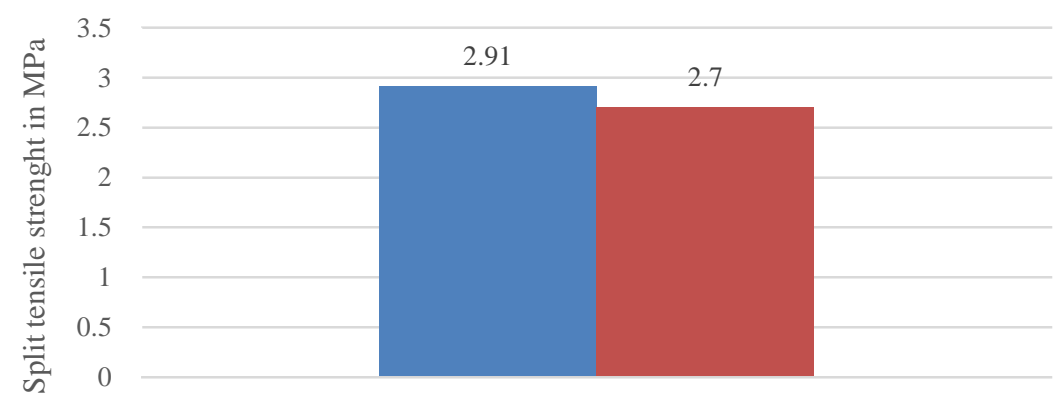

Split tensile strength at $0 \%$ vs $20 \%$ Bentonite.

- $0 \%$ Bentonite $\mathbf{2 0 \%}$ Bentonite

Fig 6: Split tensile strength at $0 \%$ vs $20 \%$

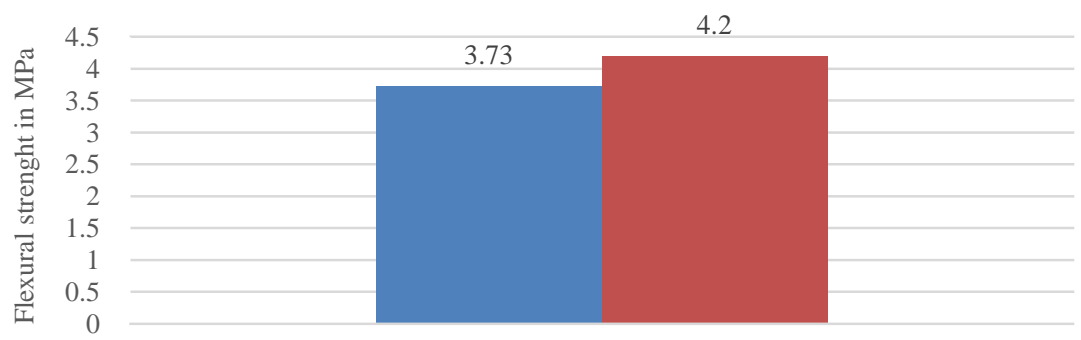

Flexural strength at $0 \%$ vs $20 \%$ Bentonite.

- $0 \%$ Bentonite $\mathbf{2} 20 \%$ Bentonite

Fig 7: Flexural strength at $0 \%$ vs $20 \%$

\section{CONCLUSION}

Based on the present experimental study the following conclusions are drawn:

- The 7 day compressive strength of $100 \%$ recycled aggregate concrete was found to increase up to about $11 \%$ with an addition of $20 \%$ Bentonite as a replacement of cement and is seen decreasing up to $16.5 \%$ when bentonite content increases to $30 \%$.

- The 28 day compressive strength of $100 \%$ recycled aggregate concrete was found to increase up to about $17.5 \%$ with an addition of $20 \%$ Bentonite as a replacement of cement and is seen decreasing up to $16 \%$ when bentonite content increases to $30 \%$. 
- The split tensile strength of the cylinders made with the addition of $30 \%$ bentonite was found to be the same as that of the split tensile strength achieved in the $100 \%$ recycled aggregate concrete. But for $5 \%, 10 \%$, $15 \%, 20 \%$ and $25 \%$ bentonite replacement, the split tensile strength is found to be lower.

- The flexural strength of 5\% and $10 \%$ bentonite replacement was found to be lesser than that of the $100 \%$ recycled aggregate but when the percentage of bentonite added to the mix was increased up to $30 \%$ replacement of cement, there has been an increase of about $17 \%$ in the flexural strength of the beams.

- The increase in compressive strength is due to the addition of bentonite and robo sand as the particle size of bentonite makes the concrete dense and workable hence it increases the strength of concrete.

- It is noted that the split tensile strength and flexural strength majorly depend on the binding material and here the binding material used was cement mixed with bentonite. Hence we can conclude that addition of bentonite increases the quality of the binding material and overall increases the quality of concrete produced.

- The research work shows that the optimum percentage to replace cement was found to be $20 \%$ where the compressive and flexural strength increase considerably with minor loss in split tensile strength. It is to be noted that the main purpose of concrete is to provide compression and hence the minor loss in split tensile strength may be overlooked.

- The workability of concrete was found to decrease by up to $35 \%$ with the change in bentonite content from $5 \%$ to $30 \%$ and hence a super plasticizer (Roofplast sp45) was used which increased the workability considerably.

\section{REFERENCES}

[1] Dhivyana $\mathbf{R}$ (2015). An experimental study on concrete using Bentonite and Steel Slag. National Conference on Research Advances in Communication, Computation, Electrical Science and Structures.

[2] A Anbarasan, M Venkatesan. (2015) Effect of Robo Sand on strength characteristic of recycled aggregate concrete. International Journal of Research in Engineering and Technology.

[3] Manjunatha M, Akshay N.K, jeevan H. (March 2016) Durability Studies on Concrete by Replacing Natural Sand with M-Sand. International Journal of Emerging Technology and Advanced Engineering.

[4] Akhil S, Ananya J, Anju P, Flemy M. (May 2016). Partial Replacement of Fine aggregate with demolished concrete fine aggregate and partial Replacement of Cement with Bentonite. International Journal of Science Technology and Engineering.

[5] Abhishek Kumar and Shweta Puri (March 2018). A New approach of using foundry sand for enhancing concrete mechanical properties. International Research Journal of Engineering and Technology.
[6] Shweta Puri, Manish Bhutani. (September 2016). Performance evaluation of concrete with partial replacement of cement with bentonite and natural coarse aggregates with recycled coarse aggregates. International Journal for Science, Management, and Technology.

[7] Sandhya V, Lalitha A, K N, Vishwanath I. (2017) Enhancing Properties of ferrocement Using Bentonite Clay And M-Sand.

[8] Praveen K, Rango R, Achyutha R. (April 2017). Effect on strength properties of concrete by partial replacement of cement with calcium bentonite and Fly Ash. International Journal of Civil Engineering and Technology.

[9] Abhinav Kumar (2018). Partial replacement of Cement and Fine aggregate by using Bentonite and Waste Sheet Glass Aggregate. International Journal of Engineering Trends and Technology.

[10] I.S. 6461 (Part 7) 1973 „Mixing, laying, compaction, curing and other construction aspects ${ }^{\text {ee }}$. BIS,New Delhi.

[11] I.S. 516-1959 „Methods of test for strength of concrete $^{\text {ee } B I S, N e w ~ D e l h i . ~}$

[12] I.S. 12269-1987, „Specification for 53 grade ordinary Portland cemente. BIS, New Delhi.

[13] I.S. 383-1970, „Specification for course and fine aggregate from natural sources for concrete ${ }^{e e}$ BIS, New Delhi.

[14] I.S. 10262-2009, „Recommended guidelines for concrete mix design ${ }^{e e}$. BIS, New Delhi. 